\title{
Intravenous Administration of Cisplatin with Magnesium Sulfate Supplement May Prevent Kidney Toxicity in Rats: The Role of Gender and Magnesium Sulfate Dose
}

\author{
Parisa Pournaderi, ${ }^{1}$ Behnaz Pourvali, ${ }^{1}$ Farzaneh Ashrafi, ${ }^{1,2}$ Ardeshir Talebi, ${ }^{1,3}$ \\ Zahra Pezeshki, ${ }^{1,4}$ and Mehdi Nematbakhsh $\mathbb{1}^{1,4,5}$ \\ ${ }^{1}$ Water \& Electrolytes Research Center, Isfahan University of Medical Sciences, Isfahan, Iran \\ ${ }^{2}$ Department of Internal Medicine, Oncology-Hematology Section, Isfahan University of Medical Sciences, Isfahan, Iran \\ ${ }^{3}$ Department of Clinical Pathology, Isfahan University of Medical Sciences, Isfahan, Iran \\ ${ }^{4}$ Department of Physiology, Isfahan University of Medical Sciences, Isfahan, Iran \\ ${ }^{5}$ Isfahan MN Institute of Basic \& Applied Sciences Research, Isfahan, Iran
}

Correspondence should be addressed to Mehdi Nematbakhsh; nematbakhsh@med.mui.ac.ir

Received 25 October 2021; Accepted 22 January 2022; Published 16 February 2022

Academic Editor: Franca Anglani

Copyright (c) 2022 Parisa Pournaderi et al. This is an open access article distributed under the Creative Commons Attribution License, which permits unrestricted use, distribution, and reproduction in any medium, provided the original work is properly cited.

Background. Cisplatin (CP) is widely used to treat various kinds of malignancies, but to avoid its side effects of nephrotoxicity and hypomagnesemia, magnesium supplementation is a subject of debate. The current study was designed to determine the protective role of intravenous magnesium sulfate $\left(\mathrm{MgSO}_{4}\right)$ against intravenous administration of CP in male and female rats. Method. In this case-control experimental study, 80 Wistar male and female rats in 12 groups of experiments were subjected to receive intravenous administration of CP accompanied with intravenous infusion of different doses ( 1,3 , and $10 \mathrm{mg} / \mathrm{ml}$ solution) of $\mathrm{MgSO}_{4}$ and were compared with the control groups. Results. CP administration increased blood urea nitrogen (BUN), creatinine (Cr), kidney tissue damage score (KTDS), and kidney weight (KW), and they were attenuated by the mid-dose of $\mathrm{MgSO}_{4}$ supplementation in female rats. However, in male rats, the increase of Cr, BUN, KTDS, and $\mathrm{KW}$ induced by $\mathrm{CP}$ was ameliorated by low, mid-, and high doses of $\mathrm{MgSO}_{4}$ supplements. The levels of these markers were significantly different between male and female rats in the mid-dose of $\mathrm{MgSO}_{4}$-treated group (BUN: $P=0.002$, Cr: $P=0.005$, KTDS: $P=0.002$, and $\mathrm{KW}: P=0.031)$. CP reduced clearance of $\mathrm{Cr}(\mathrm{ClCr})$ in both male and female rats significantly compared to the control group of saline alone $\left(P_{\text {male }}=0.002\right.$ and $\left.P_{\text {female }}=0.001\right)$, and the mid- and high doses of $\mathrm{MgSO}_{4}$ supplements improved $\mathrm{ClCr}$ in female rats. There were also sex differences in $\mathrm{ClCr}$ in mid- $(P=0.05)$ and high $(P=0.032)$ doses of $\mathrm{MgSO}_{4}$-treated groups. $\mathrm{CP}$ accompanied with the mid-dose of $\mathrm{MgSO}_{4}$ supplement reduced the KTDS $\left(P_{\text {male }}=0.04\right.$ and $\left.P_{\text {female }}=0.004\right)$ and KW $\left(P_{\text {male }}=0.002\right.$ and $\left.P_{\text {female }}=0.042\right)$ in both male and female rats significantly when compared with the $\mathrm{CP}$-alone-treated group, while there were also significant differences between the sexes (KTDS: $P=0.002$ and $\mathrm{KW}: P=0.031)$. CP accompanied with three different doses of $\mathrm{MgSO}_{4}$ supplements did not improve the serum levels of lactate dehydrogenase, urine level of sodium, malondialdehyde, urine flow, and nitrite statistically when compared with the $\mathrm{CP}$-alone-treated group. Conclusion. The renal protective effect of $\mathrm{MgSO}_{4}$ could be dose and gender related. 


\section{Introduction}

cis-Diamminedichloroplatinum, abbreviated cisplatin (CP), is a platinum-based chemotherapeutic compound widely used to treat various kinds of malignancies including testicular, ovarian, uterine, cervical, breast, head and neck, bladder, stomach, esophageal, and lung cancers [1-5]. CP was synthesized in 1844, and its chemical structure was first identified in 1893 [6], and the idea for chemotherapy was formed [7]. Finally, it became available for oncology treatment in 1978 [8].

Renal tubular dysfunction and acute and chronic renal failures are the most important side effects of $\mathrm{CP}$ that occur in 15 to $30 \%$ of patients $[9,10]$. More than $50 \%$ of CP is excreted through urine by the first day of drug administration, and the CP concentration in kidney cells is several folds higher than the other organs [11]. In fact, CP accumulates primarily in the $\mathrm{S} 3$ segment of the proximal tubule, and accumulation of $\mathrm{CP}$ in the proximal tubule frequently leads to dose-limiting CP-induced nephrotoxicity (CPIN).

Kidney toxicity induced by $\mathrm{CP}$ also occurs by the production of oxygen free radicals (ROS), especially hydroxyl radicals, which cause peroxidation of fats, oxidation of proteins and nucleic acids, and destruction of cell membranes, and these radicals reduce glomerular filtration rate (GFR) and cause acute nephrotoxicity [12]. The kidneys are able to produce a low amount of ROS in the physiological condition during metabolism, but in disease conditions and by injured cells due to the imbalance between the pro-oxidant and antioxidant, the activity of mitochondrial scavengers alters, and the ROS production increases and promotes renal injury [12].

Hypomagnesemia is a well-known complication of $\mathrm{CP}$ therapy that is seen in more than half of the CP-treated patients. Hypokalemia is another complication of $\mathrm{CP}$ therapy that may be indirect and secondary to CP-induced hypomagnesemia. Therefore, in the hydration protocol, usually, two grams of magnesium sulfate $\left(\mathrm{MgSO}_{4}\right)$ and 20 milliequivalents of potassium chloride $(\mathrm{KCl})$ add to each liter of isotonic saline to prevent hypokalemia and hypomagnesemia and to avoid the side effects of CP [13]. Magnesium $(\mathrm{Mg})$ itself has an antioxidant effect against the ROS production. The $\mathrm{Mg}$ deficiency promotes oxidative stress and apoptosis $[14,15]$. Mg also affects in other organs such as the heart [16], liver [14, 17], central nervous system [18], and gastrointestinal tract [19]. In chronic kidney disease and end-stage renal disease, the kidneys are not able to regulate $\mathrm{Mg}$ concentration [20], while $\mathrm{Mg}$ may have a protective role against chronic kidney disease [21].

GFR and plasma $\mathrm{Mg}$ concentration decrease after administration of CP at dose greater than $50 \mathrm{mg} / \mathrm{m}^{2}$, while high plasma concentration of free platinum is also directly associated with renal toxicity [22]. In diabetic CP-treated rats, $\mathrm{Mg}$ administration improved kidney tissue damage [23]. However, the intraperitoneal injection of $\mathrm{MgSO}_{4}$ was examined in rats treated with $\mathrm{CP}$, and no significant protective effect was detected [24], while Willox and Zarif showed that $\mathrm{Mg}$ administration protects the kidneys against CPIN in patients [25]. CPIN also is age and gender related in an experimental study [26]. Despite all the studies, the role of $\mathrm{MgSO}_{4}$ supplementation remains uncertain and raises some questions in the clinic related to the effective dose of $\mathrm{MgSO}_{4}$ and the role of gender. In basic studies, CP usually is evaluated by peritoneal injection than by intravenous injection, as is done in the clinic. However, in order to have an experimental model similar to what happens in the clinic, in the current study, the protective role of intravenous $\mathrm{MgSO}_{4}$ injection against intravenous administration of $\mathrm{CP}$ was investigated.

On the contrary, different studies had been performed in two genders, and concomitant use of $\mathrm{CP}$ with antioxidants and other drugs showed different responses in males and females [27-29]. It is also shown that $\mathrm{Mg}$ at different doses has a dose-dependent effect on reducing renal toxicity [30-32]. As a result, due to hypomagnesemia that occurs during $\mathrm{CP}$ administration, it is necessary to investigate the effect of different doses of $\mathrm{MgSO}_{4}$ on renal toxicity caused by $\mathrm{CP}$ in both sexes. In order to obtain this objective, $\mathrm{CP}$ accompanied with hydration protocols containing different doses of $\mathrm{MgSO}_{4}$ was administered intravenously, and the results were evaluated.

\section{Materials and Methods}

Randomly, 80 Wistar rats including male (200-300 g) and female (140-200g) were selected after adaptation to the laboratory environment with a temperature range of $23-25^{\circ} \mathrm{C}$ and $12 \mathrm{~h}$ light $/ 12 \mathrm{~h}$ dark cycle, without any restrictions on water and rat chow. All the experimental procedures were approved in advance by the Isfahan University of Medical Sciences Ethics Committee (Code no. IR.MUI.MED.REC.1399.1176).

2.1. Hydration Protocol. Usually in the clinic, for a $70 \mathrm{~kg}$ patient, a total of 2 liters of fluid is considered as hydration volume before and after CP therapy. Accordingly, in a $200 \mathrm{~g}$ animal, the volume required for hydration will be about $5.5 \mathrm{ml}$. This volume of fluid was divided into $2 \mathrm{ml}, 1.5 \mathrm{ml}$, and $2 \mathrm{ml}$ for before, during, and after CP administration, respectively. In addition, the $\mathrm{MgSO}_{4}$ supplement in the clinic is about $2 \mathrm{mg} / \mathrm{ml}$ of hydration fluid, and based on this concentration, we assigned 3 doses of $\mathrm{MgSO}_{4}$ supplements as 1,3 , and $10 \mathrm{mg} / \mathrm{ml} \mathrm{[27].}$

The time to inject these volumes of fluid was assigned as 45, 30, and 45 minutes, respectively, using a microinfusion pump (New Era Pump Systems Inc., Farmingdale, NY, USA). These volumes of fluid contained the required supplements (Table 1).

2.2. Study Groups. We used 6 animals in each group calculated as described in the literature [33]. The control groups were assigned to receive either saline (vehicle) or saline accompanied with $\mathrm{KCl}$ and mid-dose of $\mathrm{MgSO}_{4}(3 \mathrm{mg} / \mathrm{ml})$ in both sexes. The control groups did not receive CP. In addition, in order to determine the effect of $\mathrm{CP}$, a group of animals was treated with $\mathrm{CP}$ alone in each sex. In order to determine the effect of the $\mathrm{MgSO}_{4}$ supplement against CPIN, 
TABLE 1: The summary of study groups. The duration time of fluid administration before, during, and after CP therapy was 45,30 , and 45 minutes, respectively, using a microinfusion pump.

\begin{tabular}{|c|c|c|c|c|c|}
\hline \multirow{2}{*}{$\begin{array}{l}\text { Group } \\
\text { number }\end{array}$} & \multirow{2}{*}{ Gender } & \multirow{2}{*}{ Group name } & \multicolumn{3}{|c|}{ Treatment } \\
\hline & & & Before CP therapy & During CP therapy & After CP therapy \\
\hline 1,7 & $\mathrm{M}, \mathrm{F}$ & Saline & $2 \mathrm{ml}$ of saline & $1.5 \mathrm{ml}$ of saline alone & $2 \mathrm{ml}$ of saline \\
\hline 2,8 & $\mathrm{M}, \mathrm{F}$ & Saline $+\mathrm{KCl}+\mathrm{Mg} 3$ & $\begin{array}{c}2 \mathrm{ml} \text { of fluid containing saline, } \\
0.015 \mathrm{meq} / \mathrm{ml} \text { of } \mathrm{KCl} \text {, and } 3 \mathrm{mg} / \mathrm{ml} \\
\text { of } \mathrm{MgSO}_{4}\end{array}$ & $1.5 \mathrm{ml}$ of saline alone & $\begin{array}{c}2 \mathrm{ml} \text { of fluid containing saline, } \\
0.015 \mathrm{meq} / \mathrm{ml} \text { of } \mathrm{KCl} \text {, and } 3 \mathrm{mg} / \mathrm{ml} \\
\text { of } \mathrm{MgSO}_{4}\end{array}$ \\
\hline 3,9 & $\mathrm{M}, \mathrm{F}$ & $\mathrm{CP}$ & - & $\begin{array}{c}1.5 \mathrm{ml} \text { of saline } \\
\text { containing } 7.5 \mathrm{mg} / \mathrm{kg} \\
\text { of } \mathrm{CP}\end{array}$ & - \\
\hline 4,10 & $\mathrm{M}, \mathrm{F}$ & $\mathrm{CP}+\mathrm{KCl}+\mathrm{Mg} 1$ & $\begin{array}{c}2 \mathrm{ml} \text { of fluid containing saline, } \\
0.015 \mathrm{meq} / \mathrm{ml} \text { of } \mathrm{KCl} \text {, and } 1 \mathrm{mg} / \mathrm{ml}\end{array}$ & $\begin{array}{c}1.5 \mathrm{ml} \text { of saline } \\
\text { containing } 7.5 \mathrm{mg} / \mathrm{kg} \\
\text { of } \mathrm{CP}\end{array}$ & $\begin{array}{c}2 \mathrm{ml} \text { of fluid containing saline, } \\
0.015 \mathrm{meq} / \mathrm{ml} \text { of } \mathrm{KCl} \text {, and } 1 \mathrm{mg} / \mathrm{ml} \\
\text { of } \mathrm{MgSO}_{4}\end{array}$ \\
\hline 5,11 & $\mathrm{M}, \mathrm{F}$ & $\mathrm{CP}+\mathrm{KCl}+\mathrm{Mg} 3$ & $\begin{array}{c}2 \mathrm{ml} \text { of fluid containing saline, } \\
0.015 \mathrm{meq} / \mathrm{ml} \text { of } \mathrm{KCl} \text {, and } 3 \mathrm{mg} / \mathrm{ml} \\
\text { of } \mathrm{MgSO}_{4}\end{array}$ & $\begin{array}{c}1.5 \mathrm{ml} \text { of saline } \\
\text { containing } 7.5 \mathrm{mg} / \mathrm{kg} \\
\text { of } \mathrm{CP}\end{array}$ & $\begin{array}{c}2 \mathrm{ml} \text { of fluid containing saline, } \\
0.015 \mathrm{meq} / \mathrm{ml} \text { of } \mathrm{KCl} \text {, and } 3 \mathrm{mg} / \mathrm{ml} \\
\text { of } \mathrm{MgSO}_{4}\end{array}$ \\
\hline 6,12 & $\mathrm{M}, \mathrm{F}$ & $\mathrm{CP}+\mathrm{KCl}+\mathrm{Mg} 10$ & $\begin{array}{c}2 \mathrm{ml} \text { of fluid containing saline, } \\
0.015 \mathrm{meq} / \mathrm{ml} \text { of } \mathrm{KCl} \text {, and } 10 \mathrm{mg} / \\
\mathrm{ml} \text { of } \mathrm{MgSO}_{4}\end{array}$ & $\begin{array}{l}1.5 \mathrm{ml} \text { of saline } \\
\text { containing } 7.5 \mathrm{mg} / \mathrm{kg} \\
\text { of } \mathrm{CP}\end{array}$ & $\begin{array}{c}2 \mathrm{ml} \text { of fluid containing saline, } \\
0.015 \mathrm{meq} / \mathrm{ml} \text { of } \mathrm{KCl} \text {, and } 10 \mathrm{mg} / \\
\mathrm{ml} \text { of } \mathrm{MgSO}_{4}\end{array}$ \\
\hline
\end{tabular}

KCl: potassium chloride; $\mathrm{MgSO}_{4}$ : magnesium sulfate; $\mathrm{M}$ : male; $\mathrm{F}$ : female.

we designed three groups of animals treated with $\mathrm{CP}$ and different doses of $\mathrm{MgSO}_{4}$. Accordingly, the details of 12 experimental groups are explained as follows:

Groups 1 and 7 received saline continuously for a period of two hours (total injection volume was $5.5 \mathrm{ml}$ ). These groups were named "saline" groups (Table 1).

Groups 2 and 8 received saline, $\mathrm{KCl}(0.015 \mathrm{meq} / \mathrm{ml})$, and $\mathrm{MgSO}_{4}(3 \mathrm{mg} / \mathrm{ml})$ continuously for a period of two hours (total infusion volume was $5.5 \mathrm{ml}$ ). These groups were named "saline $+\mathrm{KCl}+\mathrm{Mg} 3$ " groups (Table 1).

Groups 3 and 9 received CP $(7.5 \mathrm{mg} / \mathrm{kg}$ ) (Malan Company; Athens, Greece) continuously for a period of half an hour (total infusion volume was $1.5 \mathrm{ml}$ ). These groups were named "CP" groups (Table 1).

Groups 4 and 10 received CP $(7.5 \mathrm{mg} / \mathrm{kg})$ in saline, $\mathrm{KCl}$ $(0.015 \mathrm{meq} / \mathrm{ml})$, and $\mathrm{MgSO}_{4}(1 \mathrm{mg} / \mathrm{ml})$ continuously for a period of half an hour (injection volume was $1.5 \mathrm{ml}$ ). However, before and after $\mathrm{CP}$ infusion, $2 \mathrm{ml}$ of solution containing $\mathrm{KCl}(0.015 \mathrm{meq} / \mathrm{ml})$ and $\mathrm{MgSO}_{4}$ $(1 \mathrm{mg} / \mathrm{ml})$ was administered. Therefore, the total infusion volume of fluid in each animal was $5.5 \mathrm{ml}$. These groups were named " $\mathrm{CP}+\mathrm{KCl}+\mathrm{Mgl}$ " groups (Table 1).

Groups 5 and 11 received $\mathrm{CP}(7.5 \mathrm{mg} / \mathrm{kg})$ in saline, $\mathrm{KCl}$ $(0.015 \mathrm{meq} / \mathrm{ml})$, and $\mathrm{MgSO}_{4}(3 \mathrm{mg} / \mathrm{ml})$ continuously for a period of half an hour (infusion volume was $1.5 \mathrm{ml}$ ). However, before and after $\mathrm{CP}$ infusion, $2 \mathrm{ml}$ of solution containing $\mathrm{KCl}(0.015 \mathrm{meq} / \mathrm{ml})$ and $\mathrm{MgSO}_{4}$ $(3 \mathrm{mg} / \mathrm{ml})$ was administered. Therefore, the total injection volume of fluid in each animal was $5.5 \mathrm{ml}$. These groups were named " $\mathrm{CP}+\mathrm{KCl}+\mathrm{Mg} 3$ " groups (Table 1).

Groups 6 and 12 received $\mathrm{CP}(7.5 \mathrm{mg} / \mathrm{kg})$ in saline, $\mathrm{KCl}$ $(0.015 \mathrm{meq} / \mathrm{ml})$, and $\mathrm{MgSO}_{4}(10 \mathrm{mg} / \mathrm{ml})$ continuously for a period of half an hour (infusion volume was
$1.5 \mathrm{ml}$ ). However, before and after CP infusion, $2 \mathrm{ml}$ of solution containing $\mathrm{KCl}(0.015 \mathrm{meq} / \mathrm{ml})$ and $\mathrm{MgSO}_{4}$ $(10 \mathrm{mg} / \mathrm{ml})$ was administered. Therefore, the total injection volume of fluid in each animal was $5.5 \mathrm{ml}$. These groups were named " $\mathrm{CP}+\mathrm{KCl}+\mathrm{Mg} 10$ " groups (Table 1).

2.3. Surgical and Experimental Procedures. At the beginning of the experiment, rats were anesthetized with chloral hydrate $(450 \mathrm{mg} / \mathrm{kg}$, i.p., Merck, Germany) and xylazine $(10 \mathrm{mg} / \mathrm{kg}$, i.p.). To facilitate ventilation, endotracheal intubation was down. Femoral vein catheterization for drug and fluid infusions by the microinfusion pump according to the prescribed protocol (Table 1) was performed. At the end of the drug injection, the surgical site was sutured, and after regaining consciousness, the animals were transferred to the animal house, and they were observed for six days under standard conditions. The rats were weighed daily.

At the end of the sixth day, all the animals were placed in metabolic cages, and urine from each animal was collected for 4 hours, then the animals were anesthetized again, and blood samples were taken by heart puncture. After sacrificing, the kidneys were removed and weighted rapidly. Serum samples were obtained and stored in a freezer at $-20^{\circ} \mathrm{C}$ for the measurement of biochemical factors, and the left kidney was placed in $10 \%$ formalin for histological investigation processes. The hematoxylin and eosin (H\&E) staining was applied to examine the tubular damages. The tubular lesions were scored (by a pathologist who was blinded to the study protocol) from 1 to 4 (in the form of a parameter named kidney tissue damage score (KTDS)), while the score of zero was assigned to normal tubules without damage. The KTDS was given to each sample based on percentage intensity of hyaline cast, tubular atrophy, necrosis, vacuolization, and debris in the tubule. The normal tubule was considered as $<5 \%$ damage. Grade 1 
( $5<$ damage $<25 \%)$, grade $2(25<$ damage $<50 \%)$, grade 3 $(50<$ damage $<75 \%)$, and grade 4 (damage $>75 \%$ ) were assigned to evaluate the KTDS. The serum levels of creatinine $(\mathrm{Cr})$, blood urea nitrogen (BUN), Mg, lactate dehydrogenase $(\mathrm{LDH})$, and urine levels of sodium $(\mathrm{Na})$ and $\mathrm{Cr}$ were measured using current laboratory methods. The serum levels of malondialdehyde (MDA) according to the manual methodology and nitrite by the Griess method were quantified. The clearance of $\mathrm{Cr}(\mathrm{ClCr})$ was calculated based on the renal clearance formula.

2.4. Statistical Analyses. Data were presented as mean\pm SEM. One-way analysis of variance (ANOVA) followed by LSD as post hoc was applied to compare quantitative data between the groups, and the Student $t$-test was used to compare the data between sexes. The Kruskal-Wallis and Mann-Whitney $U$ tests were employed to compare the KTDS between the groups. $P$ values $<0.05$ were considered statistically significant.

\section{Results}

3.1. Serum Levels of Creatinine (Cr), Magnesium ( $\mathrm{Mg}$ ), and Blood Urea Nitrogen (BUN). The serum levels of BUN and $\mathrm{Cr}$ increased significantly $(P<0.05)$ by $\mathrm{CP}$ alone in both male and female rats (Figure 1). However, when CP was accompanied with $\mathrm{MgSO}_{4}$ supplements (all doses), the serum mean levels of BUN and $\mathrm{Cr}$ were reduced in both sexes (Figure 1). The level of Mg was increased by CP alone in both male and female rats (Figure 1). However, the $\mathrm{MgSO}_{4}$ supplements accompanied with $\mathrm{CP}$ did not alter the serum level of $\mathrm{Mg}$ in males, but the mid-dose of $\mathrm{MgSO}_{4}$ supplement in the $\mathrm{CP}+\mathrm{KCl}+\mathrm{Mg} 3$ group decreased the serum level of $\mathrm{Mg}$ to the normal level in females (Figure 1). Finally, the mid-dose of $\mathrm{MgSO}_{4}$ supplement provided significant differences in serum levels of BUN, $\mathrm{Cr}$, and $\mathrm{Mg}$ between sexes (BUN: $P=0.002$, Cr: $P=0.005$, and Mg: $P=0.014$ ).

3.2. Creatinine Clearance (ClCr), Urine Flow (UF), and Urinary Load of $\mathrm{Na}$. CP alone or accompanied with supplements reduced $\mathrm{ClCr}$ significantly in male groups when compared with control groups $(P<0.05)$. However, the midand high doses of $\mathrm{MgSO}_{4}$ supplements improved $\mathrm{ClCr}$ in females (Figure 1). The significant differences between sexes were also observed in $\mathrm{CP}+\mathrm{KCl}+\mathrm{Mg} 3 \quad(P=0.05)$ and $\mathrm{CP}+\mathrm{KCl}+\operatorname{Mg} 10(P=0.032)$ groups. UF was significantly higher in females than in males in the saline (control) group $(P=0.033)$, and CP caused a decrease of UF in females insignificantly when compared with the saline group. No significant differences in UF were observed between CPalone-treated groups and CP accompanied with supplements treated groups in males and females (Figure 1). In addition, no significant differences in the urinary load of $\mathrm{Na}$ were detected between the groups in both males and females. However, there was a significant difference in the urinary load of $\mathrm{Na}$ between two sexes in the $\mathrm{CP}+\mathrm{KCl}+\mathrm{Mg} 1$ group $(P=0.014)$ (Figure 1).
3.3. Body Weight $(B W)$, Kidney Weight $(K W)$, and Kidney Tissue Damage Score (KTDS). As expected, CP enhanced the KTDS and percentage decrease of BW and KW in males and females compared to the control group significantly $(P<0.05)$. The three different doses of $\mathrm{MgSO}_{4}$ supplements reduced the KTDS and KW in males, and the mid- and high doses of $\mathrm{MgSO}_{4}$ supplements reduced the KTDS in females (Figure 1). There were also sex differences in the KTDS and BW change in CP accompanied with mid- $\left(P_{\mathrm{KTDS}}=0.002\right.$ and $\left.P_{\mathrm{BW}}=0.001\right)$ and high $\left(P_{\mathrm{KTDS}}=0.041\right.$ and $\left.P_{\mathrm{BW}}=0.05\right)$ doses of $\mathrm{MgSO}_{4}$-treated groups (Figure 1). The $\mathrm{KW}$ in $\mathrm{CP}$ accompanied with the mid-dose of $\mathrm{MgSO}_{4}$-treated group was significantly different between the sexes $(P=0.031)$.

3.4. Serum Malondialdehyde (MDA), Nitrite, and Lactate Dehydrogenase ( $\mathrm{LDH})$. The serum level of MDA increased insignificantly in the $\mathrm{CP}$-alone-treated group in males when compared with the saline group. However, in male sex, the serum level of MDA was not attenuated in the CP accompanied with supplement-treated groups (Figure 1(d)). No significant differences were observed in the serum MDA level between the groups in female sex.

The serum level of nitrite in CP-alone-treated rats was significantly different between the sexes $(P=0.05)$, but no significant differences were detected between the groups in both male and female rats (Figure $1(\mathrm{~d})$ ), and no statistical differences in $\mathrm{LDH}$ were detected between the groups in both sexes (Figure 1(d)).

3.5. Histological Findings. The sample images of kidney tissues in all the experimental groups are shown in Figure 2. The main important finding was related to female rats of the $\mathrm{CP}+\mathrm{KCl}+\mathrm{Mg} 3$ group which indicated that the mid-dose of $\mathrm{MgSO}_{4}$ supplement improved the tissue damage (including hyaline cast, tubular atrophy, necrosis, vacuolization, and debris) in female rats when compared with the CP-alonetreated group (Figure 2).

\section{Discussion}

As a major limiting side effect of CP therapy, it is necessary to manage CPIN to enhance the safety and efficacy of $\mathrm{CP}$ during chemotherapy. In addition, developing new prophylactic strategies plays an important role in preventing CPIN. In this study, we evaluated the nephroprotective effect of intravenous administration of $\mathrm{MgSO}_{4}$ supplement against CPIN in male and female rats.

Our results indicated that three different doses of $\mathrm{MgSO}_{4}$ more and less may prevent CPIN, and the findings are compatible with the results of previous studies [30, 34]. Particularly, coadministration of $\mathrm{CP}$ and $\mathrm{MgSO}_{4}$ significantly attenuated the elevated serum levels of BUN and $\mathrm{Cr}$ induced by the administration of CP.

It is reported that renal organic cation transporter 2 (rOCT2) and renal multidrug and toxin extrusion protein 1 (rMate1) have an important role in modulating the pharmacokinetics of renal platinum [35]. Moreover, under normal conditions, $\mathrm{Mg}$ reabsorption takes place primarily in the 


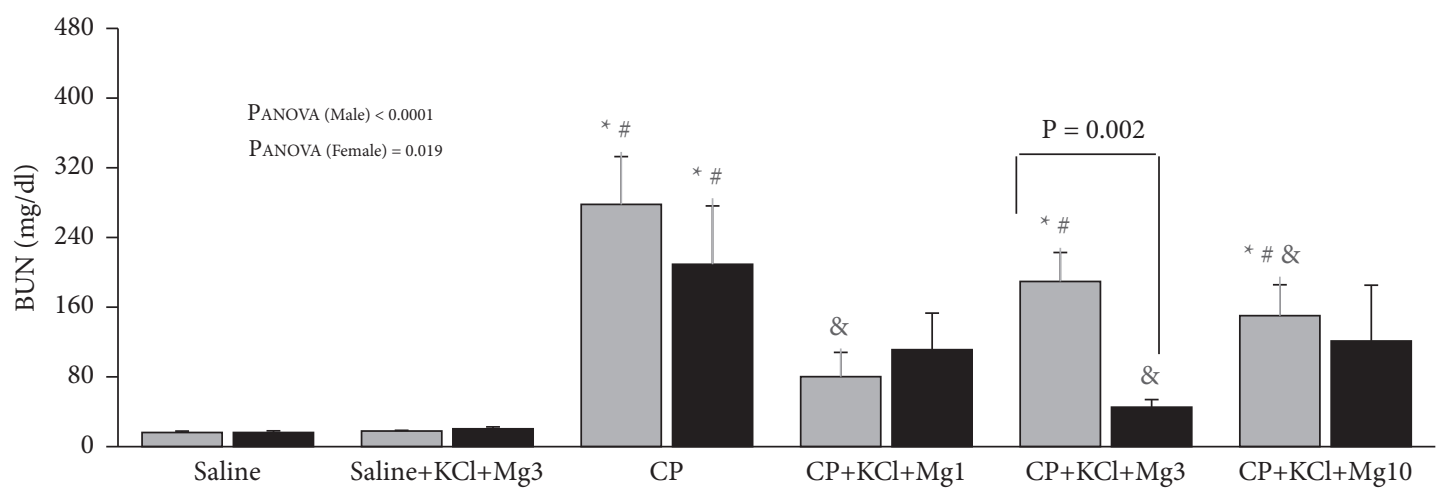

$\square$ Male

Female
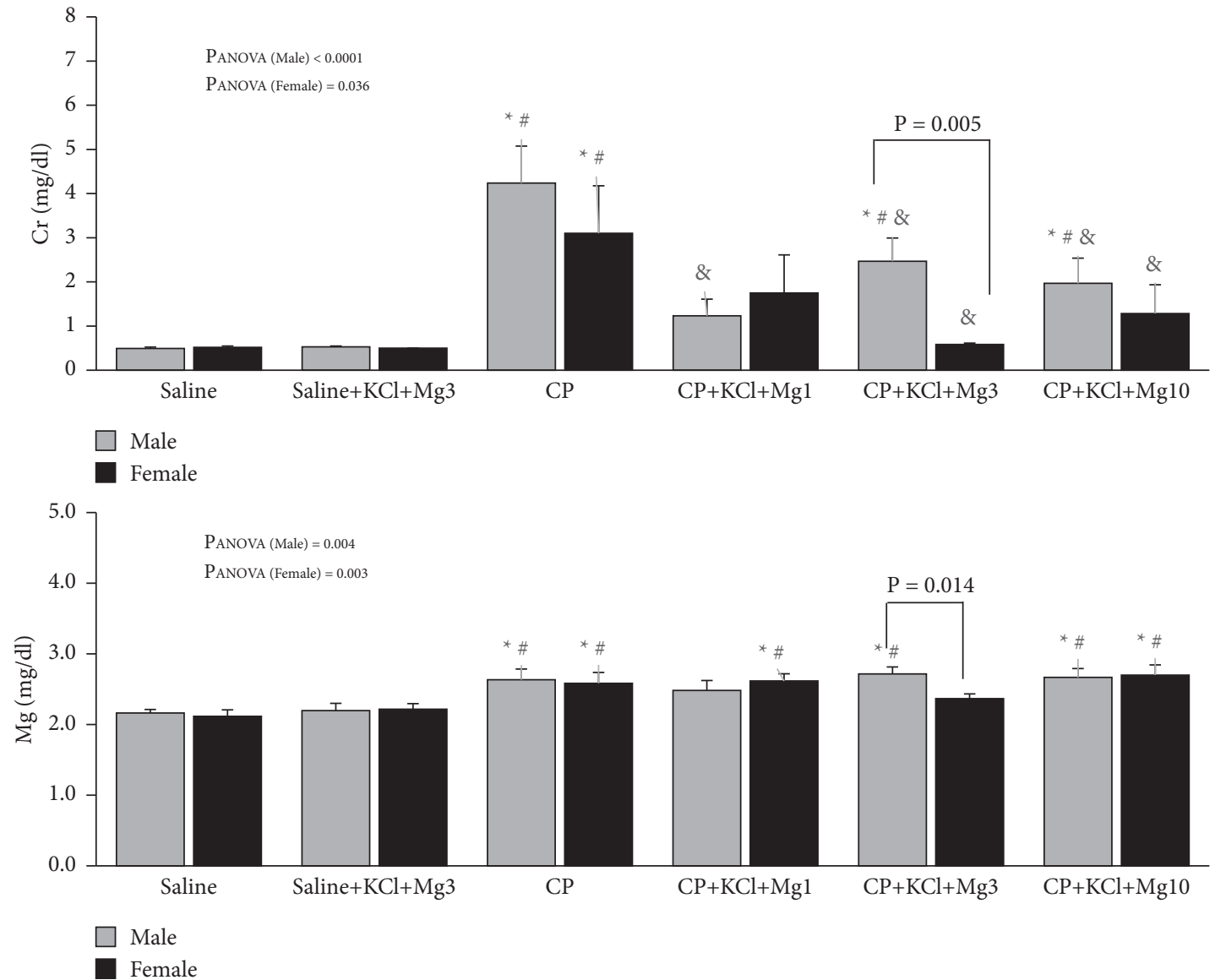

(a)

Figure 1: Continued. 


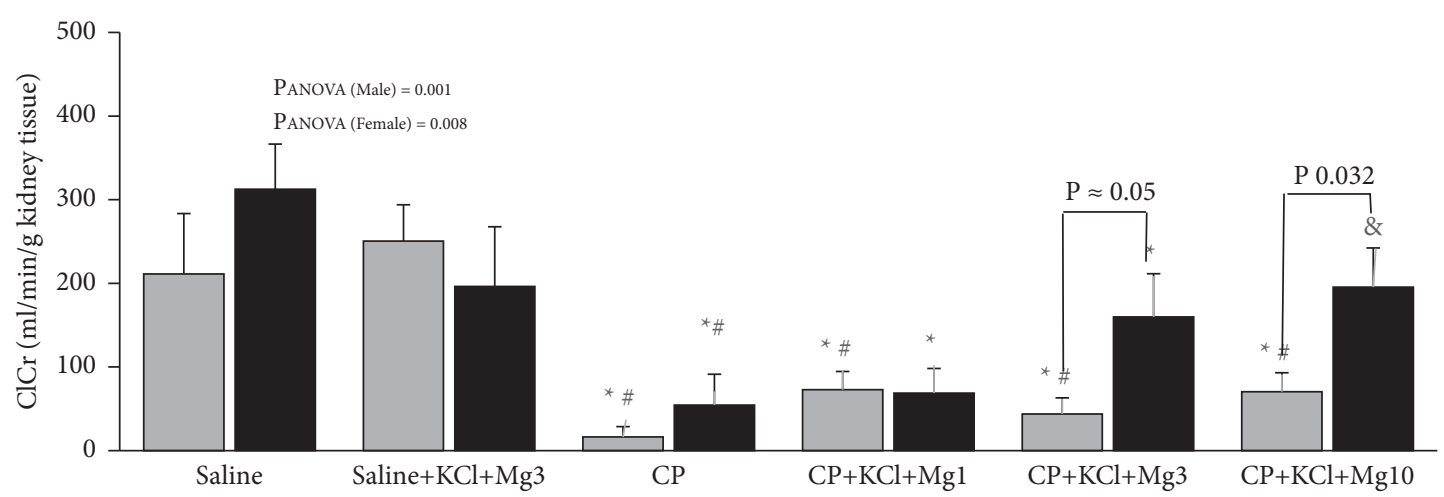

$\square$ Male

Female

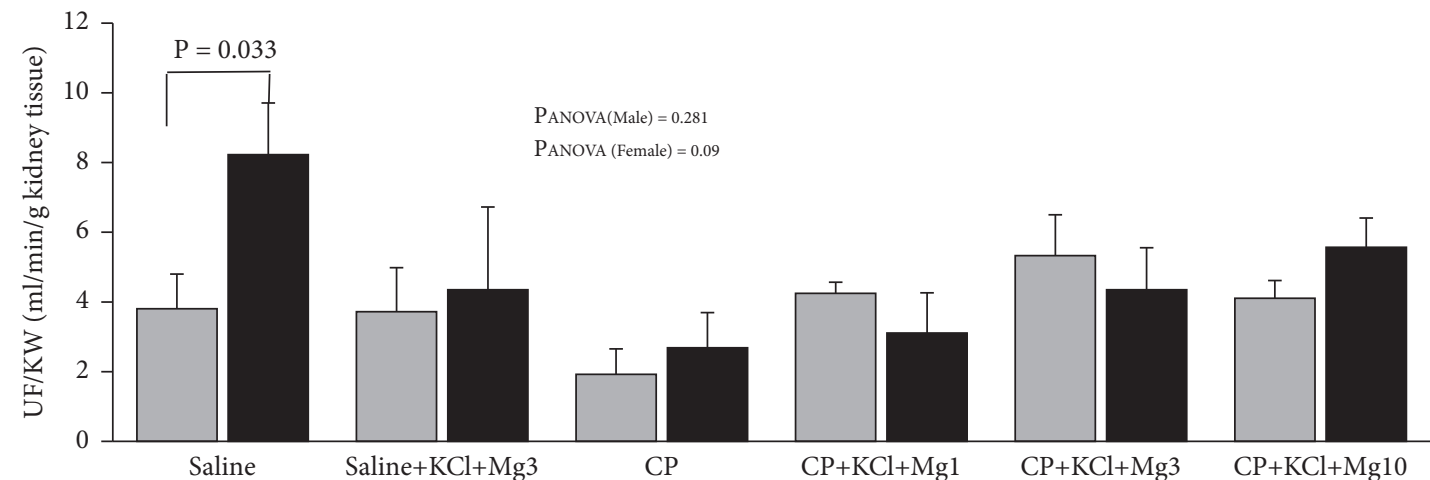

$\square$ Male

- Female

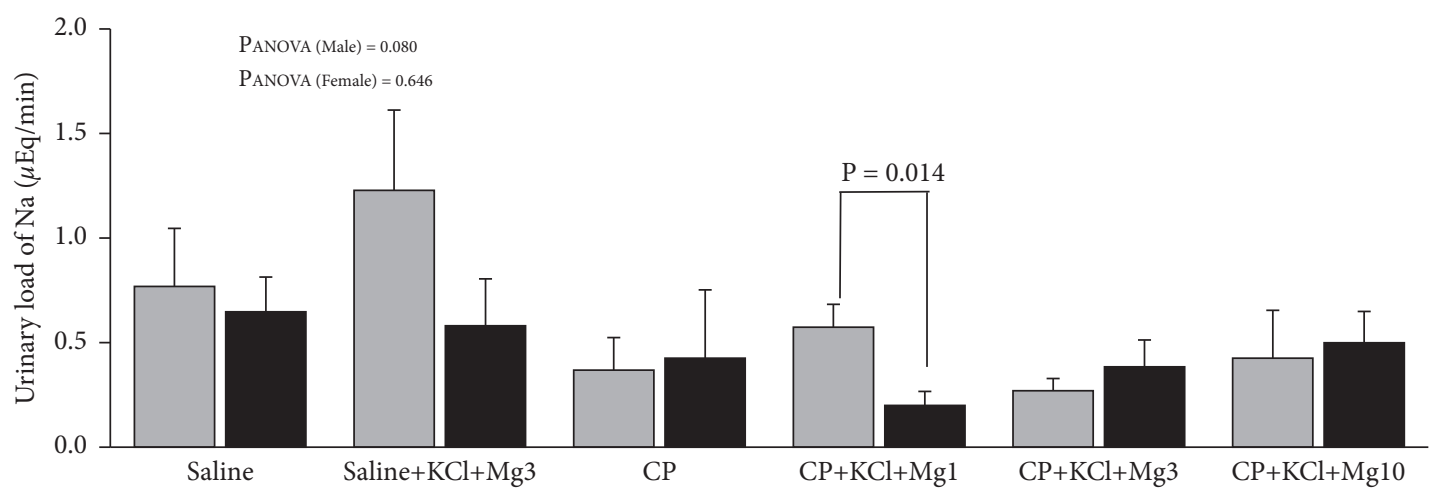

$\square$ Male

Female

(b)

Figure 1: Continued. 


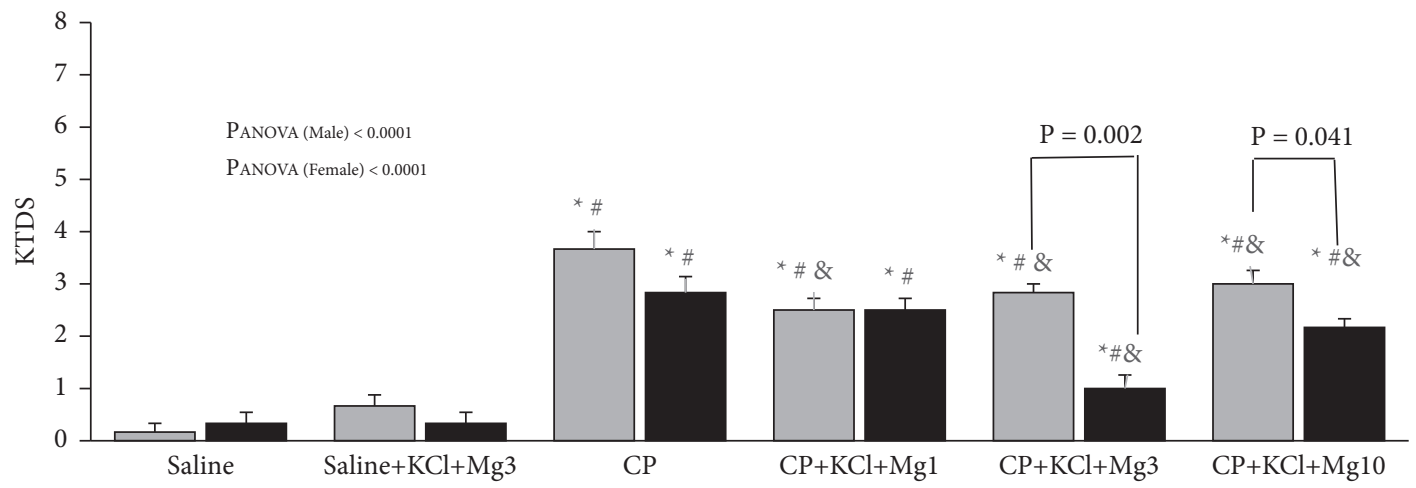

$\square$ Male

Female

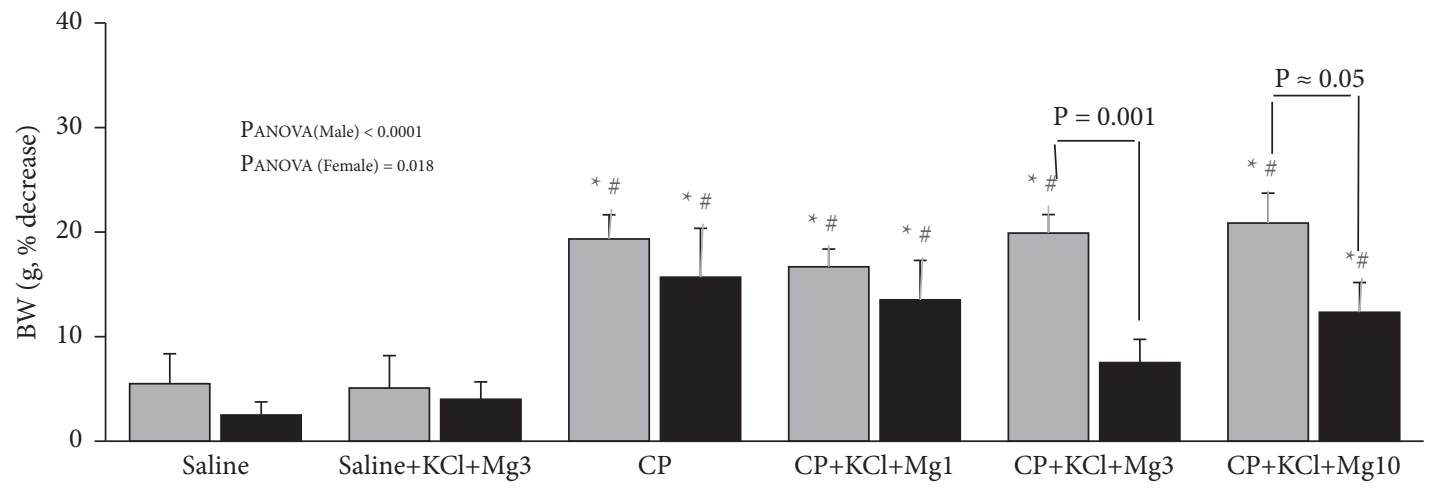

$\square$ Male

Female

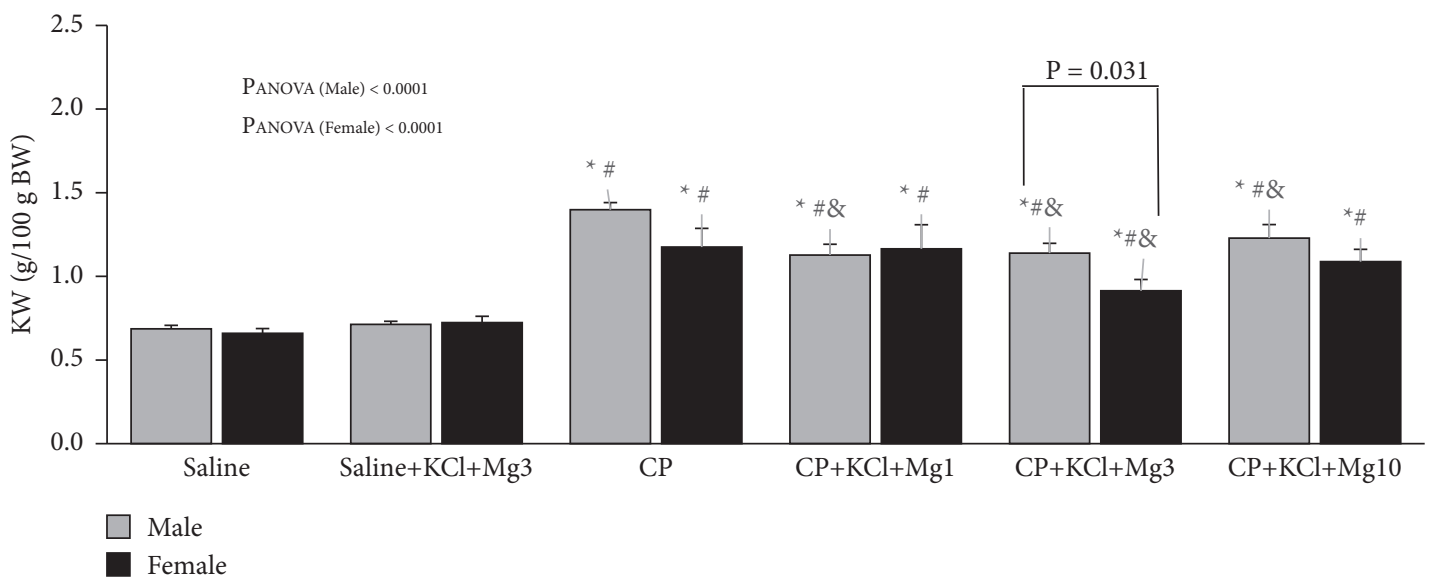

(c)

Figure 1: Continued. 


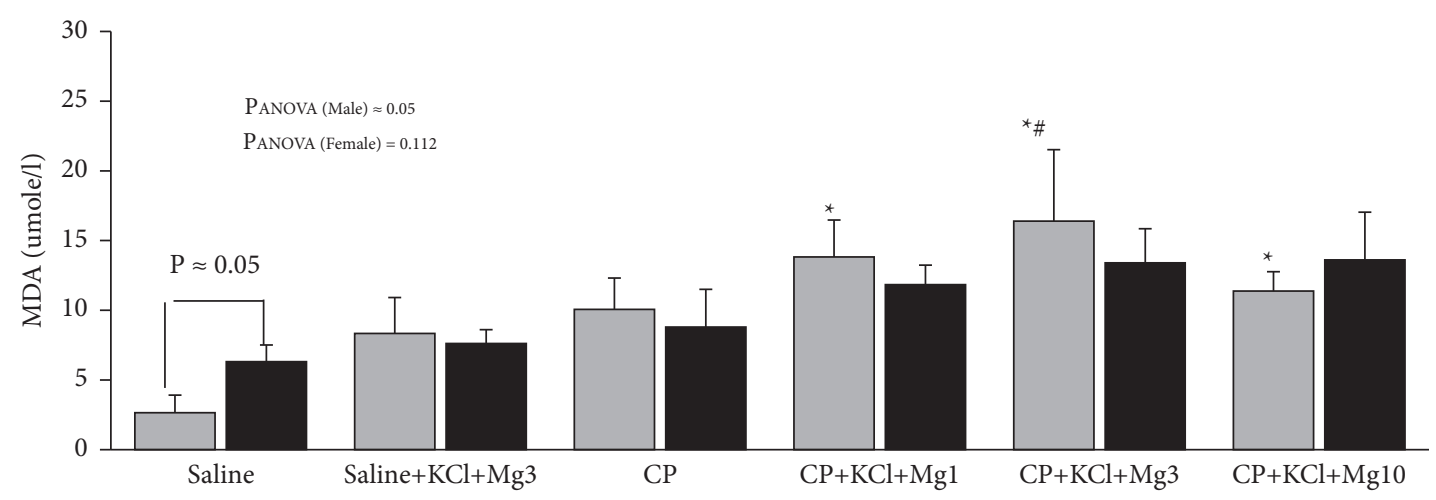

$\square$ Male

Female

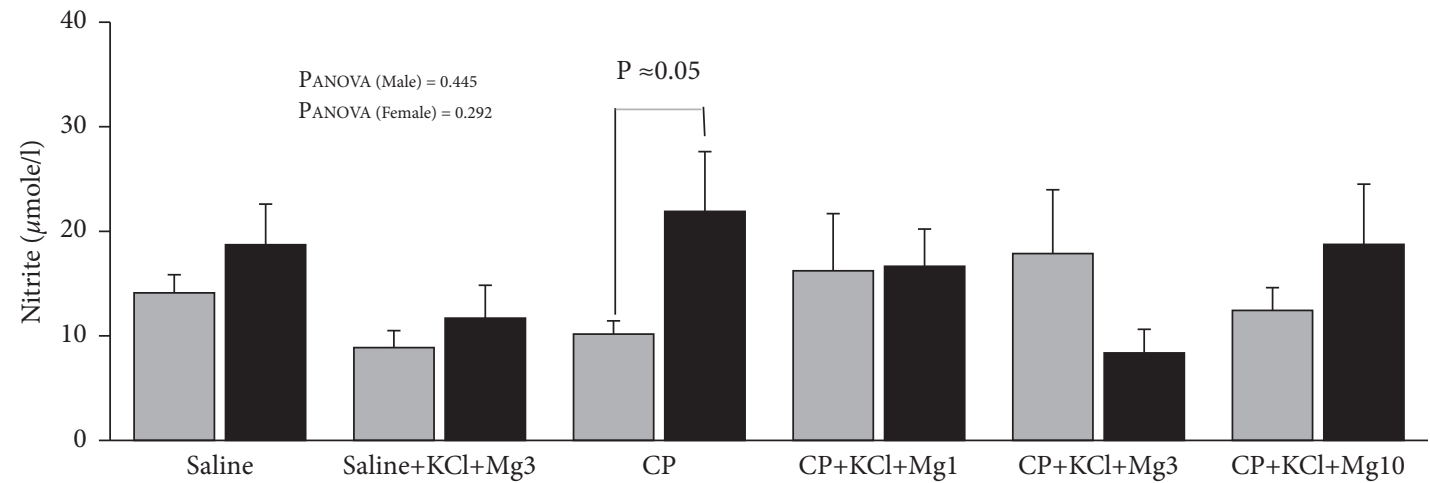

$\square$ Male

$\square$ Female

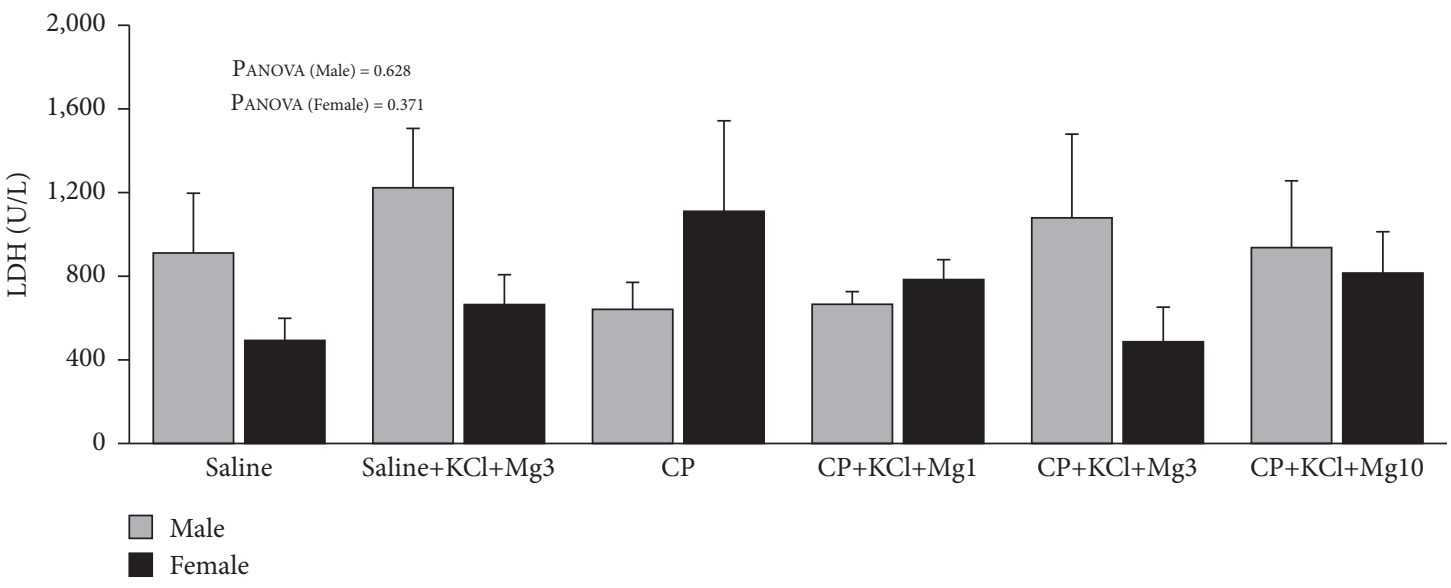

(d)

FIgURE 1: (a) The serum levels of blood urea nitrogen (BUN), creatinine (Cr), and magnesium (Mg), (b) clearance of $\mathrm{Cr}$ (ClCr), urine flow (UF), and urinary load of sodium, (c) kidney tissue damage score (KTDS), percentage decrease of body weight (BW), and normalized kidney weight (KW), and (d) the serum levels of malondialdehyde (MDA), nitrite, and lactate dehydrogenase (LDH) in 12 groups of experiments including saline, saline $+\mathrm{KCl}+\mathrm{Mg} 3, \mathrm{CP}, \mathrm{CP}+\mathrm{KCl}+\mathrm{MgSO}_{4}, \mathrm{CP}+\mathrm{KCl}+\mathrm{Mg} 1, \mathrm{CP}+\mathrm{KCL}+\mathrm{Mg} 3$, and $\mathrm{CP}+\mathrm{KCl}+\mathrm{Mg} 10$ (see Table 1 for groups' details). ${ }^{*}, \#$, and \& indicated significant differences from saline, saline $+\mathrm{KCl}+\mathrm{Mg} 3$, and $\mathrm{CP}$ groups, respectively.

ascending limb of the loop of Henle (70\%) and proximal tubule (15\%) [36], and Mg deficiency augments platinum accumulation, while $\mathrm{Mg}$ replacement therapy attenuates platinum accumulation induced by $\mathrm{Mg}$ deficiency. Also, Mg has antioxidant properties and scavenges oxygen radicals, probably by affecting the rate of spontaneous dismutation of the superoxide ion [37].
It is known that one of the mechanisms of CPIN could be oxidative stress, and $\mathrm{Mg}$ may directly relieve the oxidative stress caused by CP administration [29]. Possibly, all of the above have been involved in the reduction process of increased BUN and Cr levels by CP. It has also been reported that CPIN occurred more frequently in male than female rats, being related to the 


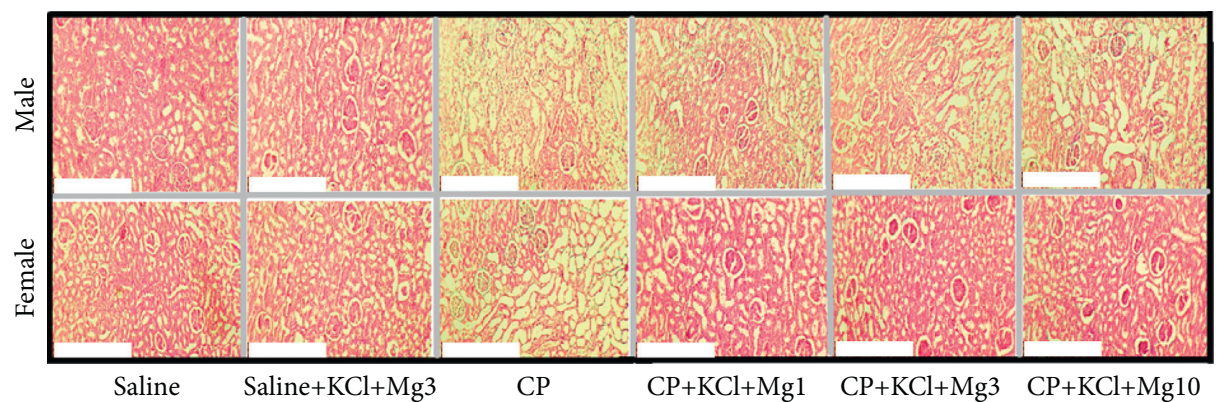

Figure 2: The sample images $(\times 100)$ of kidney tissues in 12 groups of experiments including saline, saline $+\mathrm{KCl}+\mathrm{Mg} 3, \mathrm{CP}$, $\mathrm{CP}+\mathrm{KCl}+\mathrm{MgSO}_{4}, \mathrm{CP}+\mathrm{KCl}+\mathrm{Mg} 1, \mathrm{CP}+\mathrm{KCL}+\mathrm{Mg} 3$, and $\mathrm{CP}+\mathrm{KCl}+\mathrm{Mg} 10$ (see Table 1 for groups' details). More damages were seen in the $\mathrm{CP}$-treated group when compared with non-CP-treated groups. The score of damage tissue in the female group treated with $\mathrm{CP}+\mathrm{KCl}+\mathrm{Mg} 3$ was less than the similar treated group of male. The white bar corresponds to $0.25 \mathrm{~mm} \times 1.0 \mathrm{~mm}$.

fact that the expression level of OCT2 is higher in males than in females [38].

$\mathrm{Mg}$ is the second most common intracellular cation in the body, and it is an active participant in numerous cellular processes, and it is considered as a cofactor for about 300 cellular enzymes $[39,40]$. Mg is being filtered at the glomeruli as part of the filtration-reabsorption process, and homeostasis is closely regulated by the kidney [41].

$\mathrm{Mg}$ depletion is a side effect of $\mathrm{CP}$ which occurs two weeks after CP administration [42]. Unexpectedly, we observed that the $\mathrm{Mg}$ serum level increased in all CP-treated groups six days after $\mathrm{CP}$ administration possibly due to the reduction of GFR. However, there was no difference in serum Mg levels between the groups which received CP with $\mathrm{MgSO}_{4}$ supplements, and the results are compatible with the results of previous studies [32].

In addition, the accumulation of $\mathrm{CP}$ in the renal system enhances ROS production and tumor necrosis factor alpha $(\mathrm{TNF}-\alpha)$ and induces inflammation, oxidative stress, and vascular injury $[15,43]$. It is reported that $\mathrm{Mg}$ also reduces oxidative stress [44-46]. For example, in renal ischemiareperfusion injury, the $\mathrm{MgSO}_{4}$ supplementation prevents the renal hemodynamic abnormalities such as GFR and RBF reduction via improving endothelial function [47].

$\mathrm{ClCr}$ in the $\mathrm{CP}$ group was decreased in male and female rats, and this is in agreement with the study [26]. The reduction of UF by CP may be related to a decline in GFR and renal blood flow (RBF) due to renal vascular resistance alteration $[14,48]$. However, it is observed that $\mathrm{ClCr}$ was improved in the $\mathrm{CP}+\mathrm{KCl}+\mathrm{Mg} 3$ and $\mathrm{CP}+\mathrm{KCl}+\mathrm{Mg} 10$ groups only in female rats, and possibly, the antioxidant and vasodilatory effects of $\mathrm{Mg}$ are involved.

Our results showed that weight loss in CP-treated rats is higher than control groups which may be related to disturbance in gastrointestinal or tubular absorption [49-51], as well as loss of the skeletal muscle and apoptosis [52]. The CP-induced weight loss was also confirmed by our previous studies [53-55].

The results of kidney weight and KTDS indicated that intensity of kidney toxicity in the mid-dose of $\mathrm{MgSO}_{4}$ supplementation in female rats is lower than male rats. In fact, rOCT2 is $\mathrm{Mg}$ dependent, and its expression is higher in male than female rats [38]. These phenomena increase the KTDS in male rats due to the accumulation of $\mathrm{CP}$ in the kidney [56]. It was also showed that rOCT2 expression is upregulated by testosterone, but is moderately downregulated by estradiol [57], resulting in greater renal uptake clearance of CP in male than female rats [38]. However, there have been conflicting results regarding sex as a risk factor for CPIN in clinical trials $[58,59]$.

The serum nitrite level in $\mathrm{CP}$-treated female rats was higher than male rats. The female sex hormone induces the production of nitric oxide (NO) [60]. On the contrary, $\mathrm{CP}$ induces endothelial dysfunction and increases the inducible NO synthase (iNOS) level [61]. Therefore, excessive NO reacts with superoxide and produces peroxynitrite which is a potent vasoconstrictor and easily causes oxidative damage to cellular structures $[62,63]$. In this study, the serum levels of nitrite in female rats treated with $\mathrm{CP}$ alone were more than male rats, probably due to increasing iNOS level and the presence of estrogen. $\mathrm{Mg}$ deficiency can also increase plasma NO in rats [64], and NO may enhance the CP toxicity [65]. Our finding is in agreement with others as the serum level of NO metabolite (nitrite) elevated in female rats of the CPtreated group [66]. Previous studies revealed that coadministration of $\mathrm{CP}$ and estrogen may promote the severity of toxicity due to estrogen-induced NO production [67].

The findings also showed that $\mathrm{CP}$ causes to increase serum levels of MDA in male rats insignificantly. However, coadministration of $\mathrm{MgSO}_{4}$ and $\mathrm{CP}$ did not attenuate the increased level of MDA induced by $\mathrm{CP}$ administration. It seems that the $\mathrm{MgSO}_{4}$ supplement is not able to reduce the $\mathrm{CP}$-induced oxidative stress, and more studies are needed to find the exact mechanism.

The current study had some limitations. First, the duration of the animal experiment was designed for six days. However, in order to determine the final effect of intravenous $\mathrm{MgSO}_{4}$ supplement on CPIN, more time may be needed to specify the final effects. Second, in order to determine $\mathrm{ClCr}$, 24-hour urine collection is suggested. However, we had 4 hours of urine collection.

\section{Conclusion}

Cointravenous administration of $\mathrm{MgSO}_{4}$ with $\mathrm{CP}$ ameliorates the incidence and severity of CPIN. Mg supplement attenuates the augmented $\mathrm{CP}$ accumulation induced by $\mathrm{Mg}$ 
deficiency, and it works as a cofactor of cellular enzymes, and it is therefore possible that $\mathrm{Mg}$ premedication affects the expression and function of renal transporters which is affected by CP. The protective role of $\mathrm{MgSO}_{4}$ on CPIN is also gender related. From these results, it appears that the renal protective effect of $\mathrm{MgSO}_{4}$ could be dose and gender related, and clinical trial studies need to be designed in patients to find the effective dose of $\mathrm{MgSO}_{4}$ supplement against CPIN in different genders.

\section{Data Availability}

The research data used to support the findings of this study are available from the corresponding author upon request.

\section{Conflicts of Interest}

The authors declare that there are no conflicts of interest.

\section{Authors' Contributions}

Parisa Pournaderi and Behnaz Pourvali contributed equally to this work.

\section{Acknowledgments}

This research was supported by Isfahan University of Medical Sciences (Grant no. 199634).

\section{References}

[1] U. B. Chaudhary and J. R. Haldas, "Long-term complications of chemotherapy for germ cell tumours," Drugs, vol. 63, no. 15, pp. 1565-1577, 2003.

[2] K. J. Cullen, Z. Yang, L. Schumaker, and Z. Guo, "Mitochondria as a critical target of the chemotheraputic agent cisplatin in head and neck cancer," Journal of Bioenergetics and Biomembranes, vol. 39, no. 1, pp. 43-50, 2007.

[3] D. H. Ilson, "Esophageal cancer chemotherapy: recent advances," Gastrointestinal Cancer Research: GCR, vol. 2, no. 2, pp. 85-92, 2008.

[4] N. Ismaili, M. Amzerin, and A. Flechon, "Chemotherapy in advanced bladder cancer: current status and future," Journal of Hematology \& Oncology, vol. 4, no. 1, pp. 35-11, 2011.

[5] E. E. Vokes, "Induction chemotherapy for head and neck cancer: recent data," The Oncologist, vol. 15, no. S3, pp. 3-7, 2010.

[6] S. Dasari and P. Bernard Tchounwou, "Cisplatin in cancer therapy: molecular mechanisms of action," European Journal of Pharmacology, vol. 740, pp. 364-378, 2014.

[7] B. Rosenberg, L. Van Camp, and T. Krigas, "Inhibition of cell division in Escherichia coli by electrolysis products from a platinum electrode," Nature, vol. 205, no. 4972, pp. 698-699, 1965.

[8] D. Lebwohl and R. Canetta, "Clinical development of platinum complexes in cancer therapy: an historical perspective and an update," European Journal of Cancer, vol. 34, no. 10, pp. 1522-1534, 1998.

[9] L. Kelland, "The resurgence of platinum-based cancer chemotherapy," Nature Reviews Cancer, vol. 7, no. 8, pp. 573-584, 2007.
[10] D. Wang and S. J. Lippard, "Cellular processing of platinum anticancer drugs," Nature Reviews Drug Discovery, vol. 4, no. 4, pp. 307-320, 2005.

[11] M. Kuhlmann, G. Burkhardt, and H. Köhler, "Insights into potential cellular mechanisms of cisplatin nephrotoxicity and their clinical application," Nephrology Dialysis Transplantation, vol. 12, no. 12, pp. 2478-2480, 1997.

[12] K. A. Nath and S. M. Norby, "Reactive oxygen species and acute renal failure," The American Journal of Medicine, vol. 109, no. 8, pp. 665-678, 2000.

[13] S. Hirai, S. Kaida, T. Ito, S. Hasebe, M. Ueno, and H. Udagawa, "Magnesium premedication prevents Cisplatin-induced nephrotoxicity in patients with esophageal and hypopharyngeal cancer," Gan to Kagaku Ryoho Cancer \& Chemotherapy, vol. 40, no. 6, pp. 743-747, 2013.

[14] H. Martin, B. Uring-Lambert, M. Adrian et al., "Effects of long-term dietary intake of magnesium on oxidative stress, apoptosis and ageing in rat liver," Magnesium Research, vol. 21, no. 2, pp. 124-130, 2008.

[15] B. Manuel y Keenoy, G. Moorkens, J. Vertommen, M. Noe, J. Nève, and I. De Leeuw, "Magnesium status and parameters of the oxidant-antioxidant balance in patients with chronic fatigue: effects of supplementation with magnesium," Journal of the American College of Nutrition, vol. 19, no. 3, pp. 374-382, 2000.

[16] K. Tangvoraphonkchai and A. Davenport, "Magnesium and cardiovascular disease," Advances in Chronic Kidney Disease, vol. 25, no. 3, pp. 251-260, 2018.

[17] M. Liu, H. Yang, and Y. Mao, "Magnesium and liver disease," Annals of Translational Medicine, vol. 7, no. 20, p. 578, 2019.

[18] A. Kirkland, G. Sarlo, and K. Holton, "The role of magnesium in neurological disorders," Nutrients, vol. 10, no. 6, p. 730, 2018.

[19] M. Schweigel and H. Martens, "Magnesium transport in the gastrointestinal tract," Frontiers in Bioscience: A Journal and Virtual Library, vol. 5, pp. D666-D677, 2000.

[20] E. R. van de Wal-Visscher, J. P. Kooman, and F. M. van der Sande, "Magnesium in chronic kidney disease: should we care?" Blood Purification, vol. 45, pp. 173-178, 2018.

[21] Y. Sakaguchi, T. Hamano, and Y. Isaka, "Magnesium and progression of chronic kidney disease: benefits beyond cardiovascular protection?" Advances in Chronic Kidney Disease, vol. 25, no. 3, pp. 274-280, 2018.

[22] J. r. T. Hartmann, C. Kollmannsberger, L. Kanz, and C. Bokemeyer, "Platinum organ toxicity and possible prevention in patients with testicular cancer," International Journal of Cancer, vol. 83, no. 6, pp. 866-869, 1999.

[23] N. Soltani, M. Nematbakhsh, F. Eshraghi-Jazi, A. Talebi, and F. Ashrafi, "Effect of oral administration of magnesium on cisplatin-induced nephrotoxicity in normal and streptozocininduced diabetic rats," Nephro-Urology Monthly, vol. 5, no. 4, pp. 884-890, 2013.

[24] F. Ashrafii, S. Haghshenas, M. Nematbakhsh et al., "The role of magnesium supplementation in cisplatin-induced nephrotoxicity in a rat model: no nephroprotectant effect," International Journal of Preventive Medicine, vol. 3, no. 9, p. 637, 2012.

[25] M. Z. Yeganeh, M. Vakili, A. Shahriari-Ahmadi, and M. Nojomi, "Effect of oral magnesium oxide supplementation on cisplatin-induced hypomagnesemia in cancer patients: a randomized controlled trial," Iranian Journal of Public Health, vol. 45, no. 1, p. 54, 2016. 
[26] Z. Pezeshki, M. Maleki, A. Talebi, and M. Nematbakhsh, "Age and gender related renal side effects of cisplatin in animal model," Asian Pacific Journal of Cancer Prevention: APJCP, vol. 18, no. 6, p. 1703, 2017.

[27] F. Ashrafi, M. Erfani, and S. Mousavi, "The effect of hydration therapy with and without magnesium sulfate on prevention of cisplatin-induced nephrotoxicity," Iranian Journal of Blood and Cancer, vol. 11, no. 1, pp. 13-17, 2019.

[28] F. Eshraghi-Jazi, M. Nematbakhsh, Z. Pezeshki et al., "Sex differences in protective effect of recombinant human erythropoietin against cisplatin-induced nephrotoxicity in rats," Iranian Journal of Kidney Diseases, vol. 7, no. 5, p. 383, 2013.

[29] Y. Saito, K. Okamoto, M. Kobayashi, K. Narumi, T. Yamada, and K. Iseki, "Magnesium attenuates cisplatin-induced nephrotoxicity by regulating the expression of renal transporters," European Journal of Pharmacology, vol. 811, pp. 191-198, 2017.

[30] T. Yoshida, S. Niho, M. Toda et al., "Protective effect of magnesium preloading on cisplatin-induced nephrotoxicity: a retrospective study," Japanese Journal of Clinical Oncology, vol. 44, no. 4, pp. 346-354, 2014.

[31] Y. Kubo, H. Miyata, K. Sugimura et al., "Prophylactic effect of premedication with intravenous magnesium on renal dysfunction in preoperative cisplatin-based chemotherapy for esophageal cancer," Oncology, vol. 97, no. 6, pp. 319-326, 2019.

[32] Y. Saito, M. Kobayashi, T. Yamada et al., "Premedication with intravenous magnesium has a protective effect against cisplatin-induced nephrotoxicity," Supportive Care in Cancer, vol. 25, no. 2, pp. 481-487, 2017.

[33] W. N. Arifin and W. M. Zahiruddin, "Sample size calculation in animal studies using resource equation approach," Malaysian Journal of Medical Sciences, vol. 24, no. 5, pp. 101-105, 2017.

[34] Y. Kidera, H. Kawakami, T. Sakiyama et al., "Risk factors for cisplatin-induced nephrotoxicity and potential of magnesium supplementation for renal protection," PLoS One, vol. 9, no. 7, Article ID e101902, 2014

[35] A. Yonezawa and K.-I. Inui, "Organic cation transporter OCT/SLC22A and H+/organic cation antiporter MATE/ SLC47A are key molecules for nephrotoxicity of platinum agents," Biochemical Pharmacology, vol. 81, no. 5, pp. 563-568, 2011.

[36] M. H. Solanki, P. K. Chatterjee, M. Gupta et al., "Magnesium protects against cisplatin-induced acute kidney injury by regulating platinum accumulation," American Journal of Physiology-Renal Physiology, vol. 307, no. 4, pp. F369-F84, 2014.

[37] I. B. Afanas' ev, T. B. Suslova, Z. P. Cheremisina, N. E. Abramova, and L. G. Korkina, "Study of antioxidant properties of metal aspartates," Analyst, vol. 120, no. 3, pp. 859-862, 1995.

[38] A. Yonezawa, S. Masuda, K. Nishihara, I. Yano, T. Katsura, and K.-I. Inui, "Association between tubular toxicity of cisplatin and expression of organic cation transporter rOCT2 (Slc22a2) in the rat," Biochemical Pharmacology, vol. 70, no. 12, pp. 1823-1831, 2005.

[39] K. Kjeldsen and A. Nørgaard, "Effect of magnesium depletion on $3 \mathrm{H}$-ouabain binding site concentration in rat skeletal muscle," Magnesium, vol. 6, no. 1, pp. 55-60, 1987.

[40] W. E. Wacker and A. F. Parisi, "Magnesium metabolism," New England Journal of Medicine, vol. 278, no. 13, pp. $712-717,1968$.
[41] H. Lajer and G. Daugaard, "Cisplatin and hypomagnesemia," Cancer Treatment Reviews, vol. 25, no. 1, pp. 47-58, 1999.

[42] V. Mavichak, N. L. Wong, G. A. Quamme, A. B. Magil, R. A. Sutton, and J. H. Dirks, "Studies on the pathogenesis of cisplatin-induced hypomagnesemia in rats," Kidney International, vol. 28, no. 6, pp. 914-921, 1985.

[43] M. de Araujo, L. Andrade, T. M. Coimbra, A. C. Rodrigues Jr., and A. C. Seguro, "Magnesium supplementation combined with $\mathrm{N}$-acetylcysteine protects against postischemic acute renal failure," Journal of the American Society of Nephrology: Journal of the American Society of Nephrology, vol. 16, no. 11, pp. 3339-3349, 2005.

[44] D. Luke, K. Vadiei, and G. Lopez-Berestein, "Role of vascular congestion in cisplatin-induced acute renal failure in the rat," Nephrology Dialysis Transplantation, vol. 7, no. 1, pp. 1-7, 1992.

[45] J. A. Winston and R. Safirstein, "Reduced renal blood flow in early cisplatin-induced acute renal failure in the rat," American Journal of Physiology-Renal Physiology, vol. 249, no. 4, pp. F490-F496, 1985.

[46] H. Soni, D. Kaminski, R. Gangaraju, and A. Adebiyi, "Cisplatin-induced oxidative stress stimulates renal Fas ligand shedding," Renal Failure, vol. 40, no. 1, pp. 314-322, 2018.

[47] B. Zhang, G. Ramesh, C. C. Norbury, and W. B. Reeves, "Cisplatin-induced nephrotoxicity is mediated by tumor necrosis factor-alpha produced by renal parenchymal cells," Kidney International, vol. 72, no. 1, pp. 37-44, 2007.

[48] M. R. Parvizi, M. Parviz, S. M. Tavangar et al., "Protective effect of magnesium on renal function in STZ-induced diabetic rats," Journal of Diabetes and Metabolic Disorders, vol. 13, no. 1, p. 84, 2014.

[49] U. Ammer, Y. Natochin, C. David, G. Rumrich, and K. Ullrich, "Cisplatin nephrotoxicity: site of functional disturbance and correlation to loss of body weight," Kidney \& Blood Pressure Research, vol. 16, no. 3, pp. 131-145, 1993.

[50] T. Ohno, S. Kato, M. Wakatsuki et al., "Incidence and temporal pattern of anorexia, diarrhea, weight loss, and leukopenia in patients with cervical cancer treated with concurrent radiation therapy and weekly cisplatin: comparison with radiation therapy alone," Gynecologic Oncology, vol. 103, no. 1, pp. 94-99, 2006.

[51] H. I. El-Sayyad, M. F. Ismail, F. Shalaby et al., "Histopathological effects of cisplatin, doxorubicin and 5-flurouracil (5FU) on the liver of male albino rats," International Journal of Biological Sciences, vol. 5, no. 5, p. 466, 2009.

[52] K. V. Kumar, A. A. Shifow, M. Naidu, and K. Ratnakar, "Carvedilol: a beta blocker with antioxidant property protects against gentamicin-induced nephrotoxicity in rats," Life Sciences, vol. 66, no. 26, pp. 2603-2611, 2000.

[53] F. Eshraghi-Jazi, M. Nematbakhsh, H. Nasri et al., "The protective role of endogenous nitric oxide donor (L-arginine) in cisplatin-induced nephrotoxicity: gender related differences in rat model," Journal of Research in Medical Sciences: The Official Journal of Isfahan University of Medical Sciences, vol. 16, no. 11, p. 1389, 2011.

[54] M. Nematbakhsh, Z. Pezeshki, F. Eshraghi-Jazi et al., "Vitamin E, vitamin C, or losartan is not nephroprotectant against cisplatin-induced nephrotoxicity in presence of estrogen in ovariectomized rat model," International Journal of $\mathrm{Ne}$ phrology, vol. 2012, Article ID 284896, 10 pages, 2012.

[55] M. Nematbakhsh, F. Ashrafi, T. Safari et al., "Administration of vitamin $\mathrm{E}$ and losartan as prophylaxes in cisplatin-induced nephrotoxicity model in rats," Journal of Nephrology, vol. 25, no. 3, pp. 410-417, 2012. 
[56] K. K. Filipski, R. H. Mathijssen, T. S. Mikkelsen, A. H. Schinkel, and A. Sparreboom, "Contribution of organic cation transporter 2 (OCT2) to cisplatin-induced nephrotoxicity," Clinical Pharmacology \& Therapeutics, vol. 86, no. 4, pp. 396-402, 2009.

[57] Y. Urakami, M. Okuda, H. Saito, and K.-I. Inui, "Hormonal regulation of organic cation transporter OCT2 expression in rat kidney," FEBS Letters, vol. 473, no. 2, pp. 173-176, 2000.

[58] K. Muraki, R. Koyama, Y. Honma et al., "Hydration with magnesium and mannitol without furosemide prevents the nephrotoxicity induced by cisplatin and pemetrexed in patients with advanced non-small cell lung cancer," Journal of Thoracic Disease, vol. 4, no. 6, p. 562, 2012.

[59] I. Sekine, K. Kubota, Y. Tamura et al., "Innovator and generic cisplatin formulations: comparison of renal toxicity," Cancer Science, vol. 102, no. 1, pp. 162-165, 2011.

[60] G. M. Rubanyi, A. D. Freay, K. Kauser et al., "Vascular estrogen receptors and endothelium-derived nitric oxide production in the mouse aorta. gender difference and effect of estrogen receptor gene disruption," Journal of Clinical Investigation, vol. 99, no. 10, pp. 2429-2437, 1997.

[61] K.-I. Watanabe, A. Hess, W. Bloch, and O. Michel, "Expression of inducible nitric oxide synthase (iNOS/NOS II) in the vestibule of Guinea pigs after the application of cisplatin," Anti-Cancer Drugs, vol. 11, no. 1, pp. 29-32, 2000.

[62] D. Salvemini, T. M. Doyle, and S. Cuzzocrea, "Superoxide, peroxynitrite and oxidative/nitrative stress in inflammation," Biochemical Society Transactions, vol. 34, no. Pt 5, pp. 965-970, 2006.

[63] S. Kawashima and M. Yokoyama, "Dysfunction of endothelial nitric oxide synthase and atherosclerosis," Arteriosclerosis, Thrombosis, and Vascular Biology, vol. 24, no. 6, pp. 998-1005, 2004.

[64] E. Rock, C. Astier, C. Lab et al., "Magnesium deficiency in rats induces a rise in plasma nitric oxide," Magnesium Research, vol. 8, no. 3, pp. 237-242, 1995.

[65] D. A. Wink, J. A. Cook, D. Christodoulou et al., "Nitric oxide and some nitric oxide donor compounds enhance the cytotoxicity of cisplatin," Nitric Oxide, vol. 1, no. 1, pp. 88-94, 1997.

[66] S. Jilanchi, M. Nematbakhsh, M. Bahadorani et al., "Vitamin e is a nephroprotectant agent in male but not in female in a model of Cisplatin-induced nephrotoxicity," International Scholarly Research Notices, vol. 2013, Article ID 280395, 6 pages, 2013.

[67] Q. He, C. H. Liang, and S. J. Lippard, "Steroid hormones induce HMG1 overexpression and sensitize breast cancer cells to cisplatin and carboplatin," Proceedings of the National Academy of Sciences, vol. 97, no. 11, pp. 5768-5772, 2000. 